\title{
Staphylococcus simiae sp. nov., isolated from South American squirrel monkeys
}

\author{
Roman Pantůček, ${ }^{1}$ Ivo Sedláček, ${ }^{2}$ Petr Petráš, ${ }^{3}$ Dagmar Koukalová, ${ }^{4}$ \\ Pavel Švec, ${ }^{2}$ Vlastimil Štětina, ${ }^{2}$ Marc Vancanneyt, ${ }^{5}$ Lenka Chrastinová, ${ }^{6}$ \\ Jitka Vokurková, ${ }^{6}$ Vladislava Rủžičková, ${ }^{1}$ Jiří Doškař, ${ }^{1}$ Jean Swings ${ }^{5}$ \\ and Václav Hájek ${ }^{4}$
}

Correspondence

Ivo Sedláček

ivo@sci.muni.cz

\begin{abstract}
${ }^{1}$ Department of Genetics and Molecular Biology, Faculty of Science, Masaryk University Brno, Kotlářská 2, 61137 Brno, Czech Republic

${ }^{2}$ Czech Collection of Microorganisms, Faculty of Science, Masaryk University Brno, Tvrdého 14, 60200 Brno, Czech Republic

${ }^{3}$ Reference Laboratory for Staphylococci, National Institute of Public Health, Šrobárova 48, 10042 Prague, Czech Republic

${ }^{4}$ Institute of Microbiology, Faculty of Medicine, Palacký University, Hněvotínská 3, 77515 Olomouc, Czech Republic

${ }^{5}$ BCCM/LMG Bacteria Collection, Ghent University, K. L. Ledeganckstraat 35, B-9000 Ghent, Belgium

${ }^{6}$ Zoo Olomouc, Darwinova 29, 77200 Olomouc, Czech Republic
\end{abstract}

\begin{abstract}
Eight coagulase-negative, oxidase-negative and novobiocin-susceptible staphylococcal strains were isolated from the gastrointestinal tracts of South American squirrel monkeys (Saimiri sciureus L.). These strains were differentiated from known staphylococcal species on the basis of $16 \mathrm{~S}$ rRNA gene and $h s p 60$ gene sequencing, and from the most closely related species by using DNA-DNA hybridization, ribotyping, whole-cell protein profiles and biotyping. Phylogenetic analysis based on 16S rRNA gene sequences confirmed that these strains are members of the Staphylococcus aureus species group ( $99 \%$ similarity) but are biochemically similar to Staphylococcus piscifermentans, from which they can be phenotypically distinguished by resistance to polymyxin $B$, acid production from $D$-mannitol, the inability to hydrolyse aesculin and DNA and the absence of $\alpha$-glucosidase. On the basis of these analyses, a novel species of the genus Staphylococcus is described, for which the name Staphylococcus simiae sp. nov. is proposed, with CCM $7213^{\top}\left(=\right.$ LMG $\left.22723^{\top}\right)$ as the type strain.
\end{abstract}

Staphylococci are among the most widespread of the pathogenic and opportunistic pathogenic bacteria (Kloos et al., 1992). At present, 36 staphylococcal species are known: nine of them include two subspecies, and one of them includes three subspecies (Garrity et al., 2004; Spergser et al., 2003;

Published online ahead of print on 29 April 2005 as DOI 10.1099/ ijs.0.63590-0.

Abbreviation: ERIC, enterobacterial repetitive intergenic consensus sequence.

The GenBank/EMBL/DDBJ accession numbers for the 16S rRNA and the partial $h s p 60$ gene sequences of strain CCM $7213^{\top}$ are AY727530 and AY727531.

SDS-PAGE whole-cell protein profiles, ribotype patterns, internal transcribed ribosomal spacer-PCR patterns and PFGE macrorestriction patterns of the novel isolates and reference Staphylococcus species are available as supplementary figures in IJSEM Online.
Place et al., 2003; Švec et al., 2004). Several Staphylococcus species have been isolated from non-human primates and in some cases were associated with illness and mortality, particularly in newly imported animals (Padovan \& Cantrell, 1983; Crouch et al., 1984; Stasilevich et al., 1986). An unnamed coagulase-negative and novobiocin-resistant 'Staphylococcus sp. 5' isolated from skin of squirrel monkeys has been reported previously by Kloos et al. (1976). During an outbreak of diarrhoeal disease in squirrel monkeys in a zoo in Olomouc, Czech Republic, staphylococcal strains with atypical features were isolated from both ill and healthy animals. The South American squirrel monkey (Saimiri sciureus L.) is an arboreal, small-sized, non-human primate from equatorial South America; it has always been a common sight in zoos, and laboratory-bred squirrel monkeys have long been used as an animal model in various fields of biomedical research (Rosenblum \& Coe, 1985). 
Eight Staphylococcus strains were isolated from rectal swabs or faeces obtained from different specimens of squirrel monkeys kept in Olomouc Zoo. Five strains (CCM 7213 ${ }^{\mathrm{T}}$, CCM 7214, CCM 7215, CCM 7216 and P 908) were collected in April 2000: one of them (CCM 7214) was isolated from a monkey with diarrhoea and rectal haemorrhage that died after 5 days, despite therapy with gentamicin, netilmicin, Ringer's solution and glucose. The causative agent remained unidentified. Three additional strains (CCM 7229, CCM 7230 and P 1040) were isolated in June 2004 from quarantined healthy monkeys that had just been imported from Guyanese forests; they had not come into contact with zoo monkeys. Other species of the genus Staphylococcus detected among zoo-bred squirrel monkeys were Staphylococcus aureus subsp. aureus, Staphylococcus cohnii subsp. urealyticum and Staphylococcus haemolyticus. The organisms were isolated on trypticase soy II agar plates with $5 \%$ sheep blood (Becton-Dickinson International) and subcultured on nutrient agar (Oxoid) in the presence or absence of $5 \%$ (v/v) defibrinated sheep blood at $37^{\circ} \mathrm{C}$ for $24 \mathrm{~h}$. Six representative strains have been deposited in the Czech Collection of Microorganisms (Brno, Czech Republic) as CCM $7213^{\mathrm{T}}$ ( = LMG 22723 ${ }^{\mathrm{T}}$ ), CCM 7214 (=LMG 22724), CCM 7215, CCM 7216, CCM 7229 and CCM 7230.

The following reference strains were used: S. aureus subsp. aureus $\mathrm{CCM} 885^{\mathrm{T}}$, S. aureus subsp. aureus $30 \mathrm{KR}$ (a co-isolate of the novel staphylococcal strains), S. aureus subsp. aureus NCTC 8325, Staphylococcus epidermidis CCM $2124^{\mathrm{T}}$, Staphylococcus capitis subsp. capitis CCM $2734^{\mathrm{T}}$, Staphylococcus caprae CCM $3573^{\mathrm{T}}$, Staphylococcus piscifermentans CCM $4345^{\mathrm{T}}$, CCM 4346, CCM 4347, CCM 4789 and CCM 4790 and Staphylococcus saccharolyticus LMG $22204^{\mathrm{T}}$. Morphological and physiological characteristics of the tested cultures, as well as susceptibility to furazolidone $(100 \mu \mathrm{g})$, novobiocin $(1.6 \mu \mathrm{g})$, bacitracin $(0.04 \mathrm{U})$, polymyxin $\mathrm{B}$ $(300 \mathrm{U})$ and lysostaphin $\left(200 \mathrm{mg} \mathrm{l}^{-1}\right)$ were examined by using conventional key tube or plate tests as described previously (Freney et al., 1999; Pantůček et al., 1999; Mannerová et al., 2003). Additional biochemical profile data were obtained by using the ID32 Staph, API Staph and API ZYM systems (bioMérieux). Susceptibility to other antibiotics was determined on Mueller-Hinton agar (Oxoid) by using a standard diffusion technique with a standard set of antibiotic discs for staphylococci (Oxoid).

The characteristics of the novel isolates are summarized in the species description below. The squirrel monkey strains are phenotypically close to $S$. piscifermentans (Tanasupawat et al., 1992; Pantůček et al., 1999) but differ from the latter in terms of the following biochemical characteristics: aesculin hydrolysis, DNA hydrolysis, $\alpha$ - and $\beta$-glucosidase production, acid production from D-mannitol and resistance to polymyxin B. Differentiating phenotypic features among the squirrel monkey isolates and phylogenetically and phenotypically related neighbours are indicated in Table 1. Although strains CCM 7229, CCM 7230 and P 1040 were resistant to tetracycline, the strains studied showed
Table 1. Biochemical characteristics that differentiate $S$. simiae sp. nov. (eight strains) from phylogenetically and phenotypically related Staphylococcus species

Taxa: 1, S. simiae sp. nov.; 2, S. piscifermentans; 3, S. aureus subsp. aureus; 4, S. epidermidis; 5, S. capitis subsp. capitis; 6, S. caprae. Data for related species are from Devriese et al. (1983), Kloos \& Wolfshohl (1991), Tanasupawat et al. (1991, 1992), Kloos et al. (1992), Kawamura et al. (1998), Kloos \& Bannerman (1999) and Pantůček et al. (1999). Symbols: +, $90 \%$ or more strains positive;,$- 90 \%$ or more strains negative; d, $11-89 \%$ of strains positive; $\mathrm{w}$, weak reaction; (), delayed reaction.

\begin{tabular}{|c|c|c|c|c|c|c|}
\hline Characteristic & 1 & 2 & 3 & 4 & 5 & 6 \\
\hline Coagulase & - & - & + & - & - & - \\
\hline Clumping factor & - & $-{ }^{*}$ & + & - & - & - \\
\hline \multicolumn{7}{|c|}{ Acid production (aerobically) from: } \\
\hline D-Maltose & + & d & + & + & - & $(+)$ \\
\hline D-Mannitol & + & $\mathrm{d}, \mathrm{w}$ & + & - & + & $\mathrm{d}$ \\
\hline D-Mannose & - & - & + & (d) & + & + \\
\hline D-Melezitose & $(+)$ & $\mathrm{d}$ & - & (d) & - & - \\
\hline D-Trehalose & + & + & + & - & - & $(+)$ \\
\hline $\mathrm{N}$-Acetylglucosamine & $(+)$ & d & + & - & - & - \\
\hline \multicolumn{7}{|l|}{ Production of: } \\
\hline Acetoin & - & - & + & + & $\mathrm{d}$ & + \\
\hline$\alpha$-Glucosidase $\dagger$ & - & + & $-\ddagger$ & $+\neq$ & $-\ddagger$ & $+\ddagger$ \\
\hline$\beta$-Glucosidase & $-\dagger$ & $+\dagger$ & + & (d) & - & - \\
\hline Hydrolysis of DNA & - &,$+ \mathrm{w}$ & + & - & $\mathrm{d}$ & + \\
\hline Hydrolysis of aesculin & - & + & - & - & - & - \\
\hline Resistance to polymyxin B & + & - & + & $+\S$ & - & - \\
\hline
\end{tabular}

${ }^{\star}$ Weakly positive using latex agglutination test (Murex Diagnostica). $\uparrow$ Tested using API ZYM (bioMérieux).

$\ddagger$ Result for type strain.

$\S S$. epidermidis strains were reported as resistant by Kloos \& Bannerman (1999); our results suggest that only $70 \%$ of strains are resistant (85 clinical isolates tested).

susceptibility to the other antibiotics tested, i.e. penicillin, oxacillin, erythromycin, trimethoprim/sulfamethoxazole, chloramphenicol, clindamycin, gentamicin, amoxicillin/ clavulanate, teicoplanin, vancomycin, ciprofloxacin and rifampicin.

The 16S rRNA genes of strains CCM $7213^{\mathrm{T}}$ and CCM 7229 were amplified using primers 16Sfw (5'-AGAGTTTGATCCTGGCTCAG- $3^{\prime}$ ) and 16Srev (5'-GGTTACCTTGTTACGACTT-3'). A PCR was performed according to Švec et al. (2001). Both strands of amplified DNA were sequenced by dideoxynucleotide chain termination sequencing with PCR primers; this was followed by primer walking with forward primers 271U (5'-CGGCTTACCAAGGCAACGA-3') and $1148 \mathrm{U}$ ( $5^{\prime}$-GTTGGGCACTCTAAGTTGA-3') and reverse primers 352L ( $5^{\prime}$-TCCCTACTGCTGCCTCCCG-3') and 1218L (5'-TGTAGCCCAAATCATAAGG-3'). Primer synthesis, DNA sequencing and phylogenetic analyses were performed as previously described (Mannerová et al., 2003). 
From the results obtained by DNA sequencing of the $16 \mathrm{~S}$ rRNA genes, it is clear that the squirrel monkey isolates CCM $7213^{\mathrm{T}}$ and CCM 7229 belong to the S. aureus species group (Takahashi et al., 1999), which includes two subspecies, S. aureus subsp. aureus and $S$. aureus subsp. anaerobius (Takahashi et al., 1999; Probst et al., 1998; Trülzsch et al., 2002; Spergser et al., 2003). The sequences of strains CCM $7213^{\mathrm{T}}$ and CCM 7229 were identical and showed a similarity of $99 \%$ with respect to that of $S$. aureus. The phylogenetic positions on the 16S rRNA gene tree are indicated in Fig. 1(a). The novel isolates and S. aureus differ from one another by six point mutations in the region 73-226.

The anticipated fragment for the $h s p 60$ gene of the type strain CCM $7213^{\mathrm{T}}$ was amplified with degenerate primers H279 (5'-GAATTCGAIIIIGCIGGIGAYGGIACIACIAC-3') and H280 (5' -CGCGGGATCCYKIYKITCICCRAAICCIGGIGCYTT-3'), using thermal cycler Tgradient (Biometra), Taq DNA polymerase (Invitrogen Life Technologies) and PCR thermal cycling conditions, as described previously (Goh et al., 1996). The amplicon obtained was purified by using the QIAquick PCR purification kit (Qiagen), digested with EcoRI and BamHI restriction endonucleases (Roche Diagnostics) and cloned in the pBluescript II SK $(+)$ vector (Stratagene). Both strands of DNA were sequenced with M13 forward and reverse sequencing primers. Estimation of the phylogenetic relationships of the squirrel monkey isolates and previously described Staphylococcus species (Kwok \& Chow, 2003) by means of comparison of partial hsp60 DNA sequences (Fig. 1b) showed that the highest similarity was with $S$. aureus ( $88 \%$ similarity). Likewise, Hsp60 protein sequence similarity grouped the strains close to S. aureus ( $98 \%$ identity). The next nearest related species were Staphylococcus warneri and Staphylococcus pasteuri (both sharing $96 \%$ identity), S. epidermidis, S. saccharolyticus, S. capitis, Staphylococcus muscae and Staphylococcus hominis (all sharing 95\% identity). The other species exhibited Hsp60 protein sequence identity below $94 \%$.

SDS-PAGE profile analysis, including preparation of wholecell protein extracts, densitometric analysis and reading of protein profiles as well as their numerical analysis were performed in accordance with the procedures described by Pot et al. (1994) and Švec et al. (2004). The novel isolates constituted a single cluster distinct from the type strains of phylogenetically related taxa (see Supplementary Fig. S1 available in IJSEM Online).

Various methods were used to detect intra-species genotypic relationships (Table 2). Ribotyping was performed using EcoRI (Roche Diagnostics) according to Pantůček et al. (1999). DNA was isolated by using guanidine hydrochloride extraction with the High Pure PCR template preparation kit (Roche Diagnostics). The 16S plus 23S rRNA gene hybridization profile analysis as well as cluster analysis were done using GelCompar II software (Applied Maths). The dendrogram was calculated by means of UPGMA clustering using the Dice coefficients. Three different ribotypes were
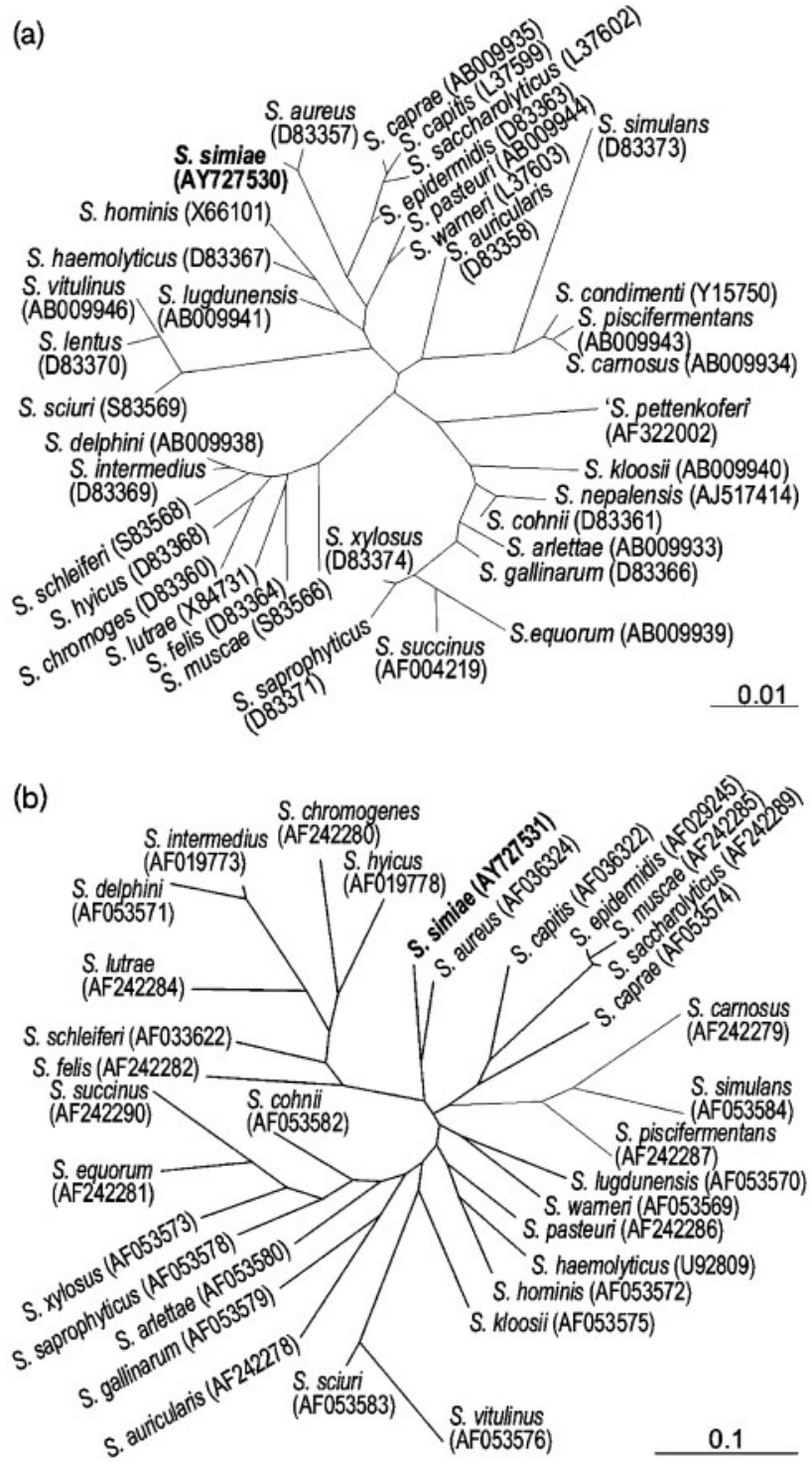

Fig. 1. Unrooted phylogenetic trees constructed on the basis of (a) 16S rRNA gene sequences and (b) hsp60 gene sequences, showing the relationship between $S$. simiae $\mathrm{sp}$. nov. and previously described staphylococci. In species that include two or more subspecies, the nominal one was used for the comparison. The maximum-likelihood method for DNA sequences, which correspond to region 55-1495 of Bacillus subtilis rrn0-16S (Kunst et al., 1997) and to a 554 nt segment of the $h s p 60$ gene, respectively, was used for the analysis. The GenBank accession numbers of the sequences of the organisms used are shown in parentheses.

recognized at $82 \%$ similarity level (see Supplementary Fig. S2). This cluster comprising all of the novel isolates was clearly distinct from other reference Staphylococcus species at a level of similarity below $62 \%$, as used by Chesneau et al. (2000) for separating different species of the genus Staphylococcus. 
Table 2. Genotype variability of eight $S$. simiae sp. nov. strains

ITS, Internal transcribed ribosomal spacer; RAPD, random amplification of polymorphic DNA; ND, none detected.

\begin{tabular}{|c|c|c|c|c|c|c|c|}
\hline \multirow[t]{2}{*}{ Strain } & \multirow{2}{*}{$\begin{array}{l}\text { Ribotype } \\
(\text { EcoRI })\end{array}$} & \multirow[t]{2}{*}{ ITS-PCR } & \multirow{2}{*}{$\begin{array}{l}\text { PFGE type } \\
\qquad(S m a I)\end{array}$} & \multirow{2}{*}{$\begin{array}{c}\text { Plasmid } \\
\text { content }(\mathbf{k b})\end{array}$} & \multicolumn{3}{|c|}{ RAPD } \\
\hline & & & & & ERIC2 & ERIC1R & 1026 \\
\hline CCM $7213^{\mathrm{T}}$ & E1 & RS-1 & A & ND & $2-a$ & $1 \mathrm{R}-\mathrm{a}$ & $\mathrm{AP}-\mathrm{a}$ \\
\hline CCM 7214 & E1 & RS-1 & B & ND & $2-b$ & $1 \mathrm{R}-\mathrm{a}$ & AP-b \\
\hline CCM 7215 & E1 & RS-1 & B & ND & $2-\mathrm{a}$ & $1 \mathrm{R}-\mathrm{a}$ & AP-c \\
\hline CCM 7216 & E1 & RS-1 & A & ND & $2-a$ & $1 \mathrm{R}-\mathrm{a}$ & AP-c \\
\hline P 908 & E1 & RS-1 & A & ND & $2-a$ & $1 \mathrm{R}-\mathrm{a}$ & AP-c \\
\hline CCM 7229 & E2 & RS-2 & $\mathrm{C} 2$ & $1 \cdot 6+6 \cdot 1$ & $2-d$ & $1 \mathrm{R}-\mathrm{b}$ & AP-d \\
\hline P 1040 & E3 & RS-2 & $\mathrm{C} 1$ & $1 \cdot 6$ & $2-c$ & $1 \mathrm{R}-\mathrm{b}$ & AP-e \\
\hline CCM 7230 & E3 & RS-2 & $\mathrm{C} 1$ & $1 \cdot 6$ & $2-c$ & $1 \mathrm{R}-\mathrm{b}$ & AP-f \\
\hline
\end{tabular}

Internal transcribed ribosomal spacer-PCR was performed as previously described (Jensen et al., 1993), using identical amplification conditions and primers G1 (5'-GAAGTCGTAACAAGG-3') and L1 (5'-CAAGGCATCCACCGT-3'). Amplification products were separated in high-resolution $3.5 \%$ gels (Eliphore agarose; Elisabeth Pharmaton) in $1 \times$ TAE buffer (0.04 M Tris-acetate, 0.001 M EDTA; pH 8.2) for $6 \mathrm{~h}$, using a $100 \mathrm{bp}$ ladder (New England Biolabs) as a molecular size marker. Two internal transcribed ribosomal spacer-PCR patterns were obtained. Although these patterns are to a certain extent related to that of S. capitis (see Supplementary Fig. S3), they are unique, share six common fragments and can be used after visual comparison with other profiles of control strains obtained by Mendoza et al. (1998) and Couto et al. (2001) for characterization of the novel isolates.

PFGE using SmaI macrorestriction pattern analysis was performed as described by Pantǔček et al. (1996). The novel isolates showed four distinct SmaI digest patterns containing 19-20 restriction fragments sized from $13 \mathrm{~kb}$ to $550 \mathrm{~kb}$ (see Supplementary Fig. S4). Patterns C1 and C2 differ from each another by the presence of $6 \cdot 1 \mathrm{~kb}$ plasmid DNA. The mean genome size $(2 \cdot 404 \pm 81 \mathrm{~kb})$ is comparable to that of the S. epidermidis species group (George \& Kloos, 1994) but lower than that of S. aureus (Pantǔček et al., 1996).

Isolation of plasmid DNA was performed by alkaline lysis and extraction using the High Pure plasmid isolation kit (Roche Diagnostics) according to the manufacturer's instructions but with minor modifications, i.e. the addition of lysostaphin (Sigma) to the lysis buffer to a final concentration of $50 \mu \mathrm{g} \mathrm{ml}^{-1}$, and prolonged lysis for $2 \mathrm{~h}$. Plasmid DNA was subjected to slab gel electrophoresis on a $0.8 \%$ agarose horizontal gel in $1 \times$ TAE buffer at $1.5 \mathrm{~V} \mathrm{~cm}^{-1}$ for $6 \mathrm{~h}$ at room temperature. A supercoiled DNA ladder (Sigma) was used to estimate plasmid size. Two types of small plasmids were detected in three strains (Table 2).

Random amplification of polymorphic DNA was performed using enterobacterial repetitive intergenic consensus sequence (ERIC)-PCR as described previously (Pantůček et al., 1999). The amplification program consisted of $2 \mathrm{~min}$ predenaturation at $95^{\circ} \mathrm{C}$ followed by 40 cycles of $1 \mathrm{~min}$ at $94{ }^{\circ} \mathrm{C}, 2 \mathrm{~min}$ at $25^{\circ} \mathrm{C}$ and $2 \mathrm{~min}$ at $74{ }^{\circ} \mathrm{C}$. Primers ERIC1R and ERIC2 (Versalovic et al., 1991) and primer 1026, the complement of ERIC1R (van Belkum et al., 1993), were used. Primer 1026 showed the highest discriminatory power and allowed the differentiation of all but two strains, CCM 7216 and $\mathrm{P}$ 908, which were also identical when typed by other DNA-based techniques (Table 2). On the other hand, the banding patterns obtained with primer ERIC1R or primer ERIC2 allowed differentiation of the monkey strains from the most closely related staphylococcal species.

The eight monkey strains did not produce enterotoxins SEA, $\mathrm{SEB}, \mathrm{SEC}_{1}, \mathrm{SEC}_{2}$, SED and SEE or toxin TSST-1 in investigations using the Reverse passive latex agglutination kit (Denka Seiken), and they gave negative results in PCRs performed according to Johnson et al. (1991).

As the novel isolates are closely related to $S$. aureus, we screened the former using different PCR assays for the detection of $S$. aureus-specific DNA sequences. All of these assays, e.g. amplification of the thermonuclease ( $n u c)$ gene (Chesneau et al., 1993), the Sa826 bp fragment (Štěpán et al., 2001), the coagulase (coa) gene (Schmitz et al., 1997), the femA regulator gene (Vannuffel et al., 1995) and the accessory gene regulator $\left(a g r_{\mathrm{Sa}}\right)$ locus (Dufour et al., 2002), gave negative results.

The DNA-DNA hybridization experiments and analysis of the DNA G $+\mathrm{C}$ content were performed as described by Mannerová et al. (2003). Comparison between strains CCM $7213^{\mathrm{T}}$ and CCM 7214 revealed $100 \%$ hybridization, but all of the DNA-DNA hybridization values between squirrel monkey isolates and the type strains of phylogenetically related species were lower than $28 \%$. Both strains had binding values of $11-13 \%$ with $S$. aureus subsp. aureus CCM $885^{\mathrm{T}}, 20-22 \%$ with S. epidermidis CCM $2124^{\mathrm{T}}, 20 \%$ with S. capitis subsp. capitis CCM $2734^{\mathrm{T}}, 19-20 \%$ with S. caprae 
CCM $3573^{\mathrm{T}}$ and $27-28 \%$ with S. saccharolyticus LMG $22204^{\mathrm{T}}$. These data clearly indicate that the staphylococcal strains from the squirrel monkeys represent a novel species. The DNA G + C contents of strains CCM $7213^{\mathrm{T}}$ and CCM 7214 were 33.8 and $31.6 \mathrm{~mol} \%$, respectively, which is within the range (30-39 mol\%) reported for other staphylococcal species (Kloos et al., 1992).

On the basis of the results obtained, the novel strains could not be assigned to any of the known staphylococcal species and therefore a polyphasic taxonomic approach was used for their analysis. From this study, we conclude that these strains represent a hitherto undescribed staphylococcal species, for which we propose the name Staphylococcus simiae sp. nov.

\section{Description of Staphylococcus simiae sp. nov.}

Staphylococcus simiae (si'mi.ae. L. gen. fem. n. simiae of/ from a monkey).

Cells are Gram-positive cocci of classical staphylococcal appearance, i.e. they occur singly, in pairs and in irregular clusters. Cells are non-motile, non-spore-forming and $0 \cdot 7-$ $0.8 \mu \mathrm{m}$ in diameter. Colonies reach $1-1.5 \mathrm{~mm}$ in diameter on glucose/yeast extract/peptone agar after $24 \mathrm{~h}$ at $36 \cdot 5^{\circ} \mathrm{C}$ and are circular, smooth, flat with low-convex centres, glistening, white and have continuous margins. The strains grow anaerobically in thioglycolate medium. Growth occurs at 15 and $45^{\circ} \mathrm{C}$ and in $12 \% \mathrm{NaCl}$. All strains are susceptible to lysostaphin, novobiocin and nitrofurantoin and are resistant to bacitracin and polymyxin $\mathrm{B}$. They are catalase-positive, oxidase-negative, coagulase-negative and clumping-factor-negative. All strains produce alkaline phosphatase, acid phosphatase, urease, leucine arylamidase, esterase and esterase-lipase and reduce nitrate to nitrite. They exhibit weak $\delta$-haemolysis activity. None of them produce acetoin, heat-stable or heat-labile nuclease, arginine arylamidase, ornithine decarboxylase, valine arylamidase, cystine arylamidase, pyrrolidonyl arylamidase, lipase, $N$-acetyl- $\beta$-glucosaminidase, $\alpha$-fucosidase, $\alpha$-galactosidase, $\alpha$-glucosidase, $\alpha$-mannosidase or $\beta$-glucuronidase. Testdependent results are obtained for the production of $\beta$-galactosidase, i.e. weakly positive when ONPG is used as a substrate and variable when 2-naphthyl $\beta$-Dgalactopyranoside is used; the type strain is $\beta$-galactosidasenegative. Similarly, cells are $\beta$-glucosidase-positive when 2 -nitrophenyl $\beta$-D-glucopyranoside is used as a substrate and negative when 6-bromo-2-naphthyl $\beta$-D-glucopyranoside is used. All strains are positive for aerobic acid production from D-fructose, D-glucose, galactose, lactose, D-maltose, Dmannitol, sucrose, D-trehalose and D-turanose. A delayed positive test result (2 days) is obtained for acidification of melezitose and $\mathrm{N}$-acetylglucosamine. Negative results are obtained for aerobic production of acid from D-cellobiose, D-raffinose, D-mannose, D-melibiose, D-ribose, xylitol, methyl $\alpha$-D-glucoside and for anaerobic fermentation of D-mannitol. Variable reactions are obtained for acid production from L-arabinose ( $3 / 8$ positive, type strain negative), sorbitol (3/8 positive, type strain negative) and $\mathrm{D}$-xylose (3/8 positive, type strain negative), for production of arginine dihydrolase (5/8 positive, type strain positive) and lecithinase (4/8 positive, type strain weakly positive) and for hydrolysis of casein (6/8 positive, type strain weakly positive), gelatin (6/8 positive, type strain positive) and Tween 80 (5/8 positive, type strain positive). No hydrolysis of elastin, aesculin, starch and tyrosine is observed.

The type strain, CCM $7213^{\mathrm{T}}\left(=\mathrm{LMG} 22723^{\mathrm{T}}\right.$ ), was isolated from the faeces of a squirrel monkey. Its characteristics are in full agreement with those given in the species description. The DNA G+C content of the type strain is $33.8 \mathrm{~mol} \%$ (by HPLC).

\section{Acknowledgements}

This study was supported, in part, by research grants 301/02/1505 and 204/02/D099 of the Grant Agency of the Czech Republic, and by long-term research programmes MSM 0021622415 and MSM 6198959205 of the Ministry of Education of the Czech Republic. We thank all colleagues involved in this study, particularly Cindy Snauwaert and Kateřina Káňová, for excellent technical assistance, and Eva Kodytková, for critical review of the manuscript. P. S. thanks the Belgian Federal Science Policy Office for a research fellowship awarded to promote S\&T cooperation with central and eastern Europe.

\section{References}

Chesneau, O., Allignet, J. \& El Solh, N. (1993). Thermonuclease gene as a target nucleotide sequence for specific recognition of Staphylococcus aureus. Mol Cell Probes 7, 301-310.

Chesneau, O., Morvan, A., Aubert, S. \& El Solh, N. (2000). The value of rRNA gene restriction site polymorphism analysis for delineating taxa in the genus Staphylococcus. Int J Syst Evol Microbiol 50, 689-697.

Couto, I., Pereira, S., Miragaia, M., Santos-Sanches, I. \& de Lencastre, H. (2001). Identification of clinical staphylococcal isolates from humans by internal transcribed spacer PCR. J Clin Microbiol 39, 3099-3103.

Crouch, T. W., Higuchi, J. H., Coalson, J. J. \& Johanson, W. G., Jr (1984). Pathogenesis and prevention of nosocomial pneumonia in a nonhuman primate model of acute respiratory failure. Am Rev Respir Dis 130, 502-504.

Devriese, L. A., Poutrel, B., Kilpper-Bälz, R. \& Schleifer, K. H. (1983). Staphylococcus gallinarum and Staphylococcus caprae, two new species from animals. Int J Syst Bacteriol 33, 480-486.

Dufour, P., Jarraud, S., Vandenesch, F., Greenland, T., Novick, R. P., Bes, M., Etienne, J. \& Lina, G. (2002). High genetic variability of the agr locus in Staphylococcus species. J Bacteriol 184, 1180-1186.

Freney, J., Kloos, W. E., Hájek, V., Webster, J. A., Bes, M., Brun, Y. \& Vernozy-Rozand, C. (1999). Recommended minimal standards for description of new staphylococcal species. Int J Syst Bacteriol 49, 489-502.

Garrity, G. M., Bell, J. A. \& Lilburn, T. G. (2004). Taxonomic outline of the Procaryotes. In Bergey's Manual of Systematic Bacteriology, 2nd edn, Release 5.0. New York: Springer. http://141.150.157.80/ bergeysoutline/main.htm. doi: 10.1007/bergeysoutline200405

George, C. G. \& Kloos, W. E. (1994). Comparison of the SmaIdigested chromosomes of Staphylococcus epidermidis and the closely related species Staphylococcus capitis and Staphylococcus caprae. Int J Syst Bacteriol 44, 404-409. 
Goh, S. H., Potter, S., Wood, J. O., Hemmingsen, S. M., Reynolds, R. P. \& Chow, A. W. (1996). HSP60 gene sequences as universal targets for microbial species identification: studies with coagulasenegative staphylococci. J Clin Microbiol 34, 818-823.

Jensen, M. A., Webster, J. A. \& Straus, N. (1993). Rapid identification of bacteria on the basis of PCR-amplified ribosomal DNA spacer polymorphisms. Appl Environ Microbiol 59, 945-952.

Johnson, W. M., Tyler, S. D., Ewan, E. P., Ashton, F. E., Pollard, D. R. \& Rozee, K. R. (1991). Detection of genes for enterotoxins, exfoliative toxins, and toxic shock syndrome toxin 1 in Staphylococcus aureus by the polymerase chain reaction. J Clin Microbiol 29, 426-430.

Kawamura, Y., Hou, X. G., Sultana, F., Hirose, K., Miyake, M., Shu, S. E. \& Ezaki, T. (1998). Distribution of Staphylococcus species among human clinical specimens and emended description of Staphylococcus caprae. J Clin Microbiol 36, 2038-2042.

Kloos, W. E. \& Bannerman, T. L. (1999). Staphylococcus and Micrococcus. In Manual of Clinical Microbiology, 7th edn, pp. 264-282. Edited by P. R. Murray, E. J. Baron, M. A. Pfaller, F. C. Tenover \& R. H. Yolken. Washington, DC: American Society for Microbiology.

Kloos, W. E. \& Wolfshohl, J. F. (1991). Staphylococcus cohnii subspecies: Staphylococcus cohnii subsp. cohnii subsp. nov. and Staphylococcus cohnii subsp. urealyticum subsp. nov. Int J Syst Bacteriol 41, 284-289.

Kloos, W. E., Zimmerman, R. J. \& Smith, R. F. (1976). Preliminary studies on the characterization and distribution of Staphylococcus and Micrococcus species on animal skin. Appl Environ Microbiol 31, 53-59.

Kloos, W. E., Schleifer, K. H. \& Götz, F. (1992). The genus Staphylococcus. In The Prokaryotes: a Handbook on the Biology of Bacteria: Ecophysiology, Isolation, Identification, Applications, 2nd edn, vol. 2, pp. 1369-1420. Edited by A. Balows, H. G. Trüper, M. Dworkin, W. Harder \& K. H. Schleifer. New York: Springer.

Kunst, F., Ogasawara, N., Moszer, I. \& 148 other authors (1997). The complete genome sequence of the Gram-positive bacterium Bacillus subtilis. Nature 390, 249-256.

Kwok, A. Y. \& Chow, A. W. (2003). Phylogenetic study of Staphylococcus and Macrococcus species based on partial hsp60 gene sequences. Int J Syst Evol Microbiol 53, 87-92.

Mannerová, S., Pantůček, R., Doškař, J., Švec, P., Snauwaert, C., Vancanneyt, M., Swings, J. \& Sedláček, I. (2003). Macrococcus brunensis sp. nov., Macrococcus hajekii sp. nov. and Macrococcus lamae sp. nov., from the skin of llamas. Int J Syst Evol Microbiol 53, $1647-1654$

Mendoza, M., Meugnier, H., Bes, M., Etienne, J. \& Freney, J. (1998). Identification of Staphylococcus species by 16S-23S rDNA intergenic spacer PCR analysis. Int J Syst Bacteriol 48, 1049-1055.

Padovan, D. \& Cantrell, C. (1983). Causes of death of infant rhesus and squirrel monkeys. J Am Vet Med Assoc 183, 1182-1184.

Pantůček, R., Götz, F., Doškař, J. \& Rosypal, S. (1996). Genomic variability of Staphylococcus aureus and the other coagulase-positive Staphylococcus species estimated by macrorestriction analysis using pulsed-field gel electrophoresis. Int J Syst Bacteriol 46, 216-222.

Pantůček, R., Sedláček, I., Doškař, J. \& Rosypal, S. (1999). Complex genomic and phenotypic characterization of the related species Staphylococcus carnosus and Staphylococcus piscifermentans. Int J Syst Bacteriol 49, 941-951.

Place, R. B., Hiestand, D., Gallmann, H. R. \& Teuber, M. (2003). Staphylococcus equorum subsp. linens, subsp. nov., a starter culture component for surface ripened semi-hard cheeses. Syst Appl Microbiol 26, 30-37.
Pot, B., Vandamme, P. \& Kersters, K. (1994). Analysis of electrophoretic whole-organism protein fingerprints. In Chemical Methods in Prokaryotic Systematics, pp. 493-521. Edited by M. Goodfellow \& A. G. O'Donnell. Chichester: Wiley.

Probst, A. J., Hertel, C., Richter, L., Wassill, L., Ludwig, W. \& Hammes, W. P. (1998). Staphylococcus condimenti sp. nov., from soy sauce mash, and Staphylococcus carnosus (Schleifer and Fischer 1982) subsp. utilis subsp. nov. Int J Syst Bacteriol 48, 651-658.

Rosenblum, L. A. \& Coe, C. L. (1985). Handbook of Squirrel Monkey Research. New York: Plenum.

Schmitz, F. J., MacKenzie, C. R., Hofmann, B., Verhoef, J., Finken-Eigen, M., Heinz, H. P. \& Kohrer, K. (1997). Specific information concerning taxonomy, pathogenicity and methicillin resistance of staphylococci obtained by a multiplex PCR. J Med Microbiol 46, 773-778.

Spergser, J., Wieser, M., Taubel, M., Rossello-Mora, R. A., Rosengarten, R. \& Busse, H. J. (2003). Staphylococcus nepalensis sp. nov., isolated from goats of the Himalayan region. Int J Syst Evol Microbiol 53, 2007-2011.

Stasilevich, Z. K., Trots, A. A. \& Dzhikidze, E. K. (1986). Biotyping of staphylococci isolated from monkeys. Mikrobiol Zh 48, 38-41 (in Russia).

Štěpán, J., Pantůček, R., Růžičková, V., Rosypal, S., Hájek, V. \& Doškař, J. (2001). Identification of Staphylococcus aureus based on PCR amplification of species specific genomic $826 \mathrm{bp}$ sequence derived from a common 44-kb SmaI restriction fragment. Mol Cell Probes 15, 249-257.

Švec, P., Devriese, L. A., Sedláček, I., Baele, M., Vancanneyt, M., Haesebrouck, F., Swings, J. \& Doškař, J. (2001). Enterococcus haemoperoxidus sp. nov and Enterococcus moraviensis sp. nov., isolated from water. Int J Syst Evol Microbiol 51, 1567-1574.

Švec, P., Vancanneyt, M., Sedláček, I., Engelbeen, K., Štetina, V., Swings, J. \& Petráš, P. (2004). Reclassification of Staphylococcus pulvereri Zakrzewska-Czerwinska et al. 1995 as a later synonym of Staphylococcus vitulinus Webster et al. 1994. Int J Syst Evol Microbiol 54, 2213-2215.

Takahashi, T., Satoh, I. \& Kikuchi, N. (1999). Phylogenetic relationships of 38 taxa of the genus Staphylococcus based on $16 \mathrm{~S}$ rRNA gene sequence analysis. Int J Syst Bacteriol 49, 725-728.

Tanasupawat, S., Hashimoto, Y., Ezaki, T., Kozaki, M. \& Komagata, K. (1991). Identification of Staphylococcus carnosus strains from fermented fish and soy sauce mash. J Gen Appl Microbiol 37, 479-494.

Tanasupawat, S., Hashimoto, Y., Ezaki, T., Kozaki, M. \& Komagata, K. (1992). Staphylococcus piscifermentans sp. nov., from fermented fish in Thailand. Int J Syst Bacteriol 42, 577-581.

Trülzsch, K., Rinder, H., Trček, J., Bader, L., Wilhelm, U. \& Heesemann, J. (2002). "Staphylococcus pettenkoferi", a novel staphylococcal species isolated from clinical specimens. Diagn Microbiol Infect Dis 43, 175-182.

van Belkum, A., Bax, R., Peerbooms, P., Goessens, W. H., van Leeuwen, N. \& Quint, W. G. (1993). Comparison of phage typing and DNA fingerprinting by polymerase chain reaction for discrimination of methicillin-resistant Staphylococcus aureus strains. J Clin Microbiol 31, 798-803.

Vannuffel, P., Gigi, J., Ezzedine, H., Vandercam, B., Delmee, M., Wauters, G. \& Gala, J.-L. (1995). Specific detection of methicillinresistant Staphylococcus species by multiplex PCR. J Clin Microbiol 33, 2864-2867.

Versalovic, J., Koeuth, T. \& Lupski, J. R. (1991). Distribution of repetitive DNA sequences in eubacteria and application to fingerprinting of bacterial genomes. Nucleic Acids Res 19, 6823-6831. 